\title{
Knowledge and Attitude Related to Antibiotic Use Among Students of a Kathmandu Based High School
}

\author{
Manoj Sharma, Sammodavardhana Kaundinnyayana and Premlata Das
}

Department of Pharmacology, Nepalese Army Institute of Health Sciences, Sanobharyang, Kathmandu, Nepal

\begin{abstract}
Introduction: Antibiotic resistance has been described by World Health Organisation as a major global health problem that threats our ability to treat common infectious diseases and needs urgent action. Among many other factors, knowledge and behaviour of community members that lead to inappropriate use of antibiotic highly contributes to development and spread of antimicrobial resistance. Hence this study has been undertaken with the aim to assess the knowledge and attitude related to antibiotic use among high school students.
\end{abstract}

Methods: A cross-sectional questionnaire based survey was conducted at a Kathmandu based highschool. The data were collected via self-administered questionnaire after verbal consent for voluntary participation. There were nine questions related to knowledge and five questions related to attitude. Data were aggregated to compile frequency distribution tables and the percentages of responses were calculated.

Result: A total of 232 students participated in the study. In the questions related to knowledge, nearly $62 \%$ of the students agreed to the statement "Antibiotics are needed to cure most coughs and cold". About 19\% students were not sure whether antibiotics can kill the useful bacteria in our body. In the attitude part, 53.87\% students responded that they stop taking antibiotics when they start to feel better and $59.91 \%$ students responded that they buy antibiotics on their own from a pharmacist when needed.

Conclusions: The deficiencies in basic understanding about the nature and use of antibiotics and casual attitude in their use among high school students is a matter of great concern as it poses many serious problems including promotion of antibiotic resistance

Key words: Antibiotics; Attitude; High-school; Knowledge; Resistance

Correspondence: Manoj Sharma, Department of Pharmacology, Nepalese Army Institute of Health Sciences, Sanobharyang, Kathmandu, Nepal. Email: drmanojpharma@gmail.com

DOI: $10.3126 / \mathrm{mj}$ sbh.v20i2.36409

Submitted on: 2021-04-12

Accepted on: 2021-06-16 


\section{INTRODUCTION}

Antibiotic resistance has been described by World Health Organisation as a major global health problem that threats our ability to treat common infectious diseases and needs urgent action. ${ }^{1-3}$ It has potentially dreadful health hazards which have been underestimated in low and middle income countries. ${ }^{4}$ In recent years, resistance to antimicrobial agents that were previously effective has emerged or re-emerged in many regions causing a global health threat and economic consequences. ${ }^{5}$ Overuse, underuse, and misuse of antibiotics has contributed to emergence of antimicrobial resistance worldwide. ${ }^{6}$ Emergence of antibiotic resistance to the available antibiotics results in treatment failures and, as a result, leads to longer and more severe illness episodes with higher costs and higher mortality rates. ${ }^{7}$ Among many other factors, knowledge and behaviour of community members that lead to inappropriate antibiotic use also contributes to development and spread of antimicrobial resistance..$^{8,9}$

Studies have reported that rational use of antibiotics can be promoted by changing the knowledge and prescribing behaviour of healthcare professionals. ${ }^{10-12}$ It has also been suggested that giving comprehensive trainings and organising frequent activities for creating awareness on antimicrobial resistance for students in medical disciplines could be an effective and encouraging approach to bring rational prescribing behaviour in future practitioners. ${ }^{13}$ Community awareness programs including inclusion of relevant information in general education are important as problematic behaviours like demand of antibiotics or self-medication and poor compliance of antibiotics pose threat to rational use of antibiotics and contribute to development of antibiotic resistance. ${ }^{14}$

In our country too, self-medication with antibiotics and inappropriate use of antibiotics is common. ${ }^{15}$ However, there is limited evidence regarding antibiotic resistance in Nepal. ${ }^{16}$ Few studies have been done among health professionals, medical students as well as general public ${ }^{5,15,16}$ but studies targeting non-medical and high school students with regard to their knowledge and attitude related to antibiotic use are lacking. It is an irony because their knowledge, attitude, and behaviour regarding the use of antibiotics is likely to reflect the impact of school education on the use of medicines in general and towards antibiotics in particular. These types of studies are helpful to identify the information to be included for educational intervention at school level for imparting appropriate knowledge on antibiotic use that should lead to changes in behaviour. As a large proportion of population is in high schools, interventions at this level may also have tremendous effect with regard to promotion of rational antibiotic use from the part of public. This study thus aims to assess the knowledge and attitude related to antibiotic use among high school students from a Kathmandu based high school (Jubilant College, Kalimati).

\section{METHODS}

The research proposal was approved by the Institutional Review Committee (IRC) on December 2020. A cross sectional questionnaire based survey to assess the knowledge and attitude related to antibiotic use was designed to be carried out at a Kathmandu based high-school. Based on the literature search, the questionnaire was adapted from previous studies done in the United Kingdom ${ }^{17,18}$ and tailored to suit the target population of this study. The study was conducted in between January 2021 to March 2021 after getting IRC approval. Students of Grades 11 and 12 from management and science streams were included in the study as the representative group and the sample size was targeted to include all the students of Grades 11 and 12 of the school. Verbal consent was taken from the school Principal as well as from the students before they were asked to fillup the questionnaire forms. Students were informed beforehand that the participation was voluntary. There were nine questions related to knowledge and five questions related to attitude. In the knowledge part, students had to respond to the questions by ticking in a Likert scale whose responses ranged from "strongly agree" to "strongly disagree" whereas in attitude part, they simply had to tick in "Yes" if they agreed to the question or "No" if they disagreed to it. Data was aggregated to compile frequency distribution tables and the percentages of responses were recorded. To simplify the results' presentation in the text, those who answered "strongly agree" or "agree" are 
Table 1. Responses on the statements related to antibiotic use and resistance

$\begin{aligned} & \text { Statements related to antibiotic use and } \\ & \text { resistance }\end{aligned}$
$\begin{aligned} & \text { responsect } \\ & \text { response }\end{aligned}$

- Different antibiotics are needed to cure Agree different infections

- Antibiotics are effective against all types Disagree of infections

- Antibiotics can kill the useful bacteria in our body too

- Antibiotics are helpful to cure most coughs and cold

- If you get side effects during a course of antibiotic treatment, you would not take the next dose and contact a physician

- If you get some kind of skin allergy (e.g. rashes) when using an antibiotic, you would not use the same antibiotic again

- Unnecessary use of antibiotics can increase the chance of resistance of bacteria to them and decrease the future effectiveness

- Using full course of antibiotic can lessen the chance of emergence of resistance

- Poor drug quality and adulterated antibiotic preparation can cause development of antibiotic resistance

classified as "agreed" and those who answered "strongly disagree" or "disagree" are considered as "disagree". The response "Undecided" was interpreted as incorrect. The correct responses on the knowledge based questions are listed below on Table1.

\section{RESULT}

Out of a total 300 students, 232 students returned the filled questionnaire forms. The frequency of the different responses for the knowledge related questions and attitude related Yes / No questions are given in the table 2 and table 3 respectively.

In the questions related to knowledge (Table 2), nearly $62 \%$ of the students responded that they agree to the statement "Antibiotics are needed to cure most coughs and cold". Similarly, 19.39\% students responded that they are not sure whether antibiotics can kill the useful bacteria in our body. In the attitude part (Table 3), 53.87\% students incorrectly responded that they stop taking antibiotics when they start to feel better during the course of treatment and 59.91\% students responded that they buy antibiotics on their own from a pharmacist when needed.

\section{DISCUSSION}

This study aims to generate a general view and the existing knowledge and the attitude of high school

Table 2. Questionnaire to assess knowledge

\begin{tabular}{|c|c|c|c|c|c|c|}
\hline SN & Questions & 1 & 2 & 3 & 4 & 5 \\
\hline 1 & $\begin{array}{l}\text { Different antibiotics are needed to cure different } \\
\text { infections }\end{array}$ & $45.6 \%$ & $42.2 \%$ & $5.17 \%$ & $5.17 \%$ & $0.43 \%$ \\
\hline 2 & Antibiotics are effective against all types of infections & $9.48 \%$ & $24.58 \%$ & $23.7 \%$ & $33.62 \%$ & $8.62 \%$ \\
\hline 3 & $\begin{array}{l}\text { Antibiotics can kill the useful bacteria present in our body } \\
\text { too }\end{array}$ & $26.29 \%$ & $39.65 \%$ & $19.39 \%$ & $10.34 \%$ & $2.15 \%$ \\
\hline 4 & Antibiotics are helpful to cure most coughs and cold & $17.24 \%$ & $44.39 \%$ & $12.93 \%$ & $12.06 \%$ & $11.2 \%$ \\
\hline 5 & $\begin{array}{l}\text { If you get side effects during a course of antibiotic } \\
\text { treatment, you would not take the next dose and contact a } \\
\text { physician }\end{array}$ & $50.86 \%$ & $20.68 \%$ & $10.77 \%$ & $11.63 \%$ & $4.31 \%$ \\
\hline 6 & $\begin{array}{l}\text { If you get some kind of skin allergy (e.g. rashes) when } \\
\text { using an antibiotic, you would not use the same antibiotic } \\
\text { again in future }\end{array}$ & $28.01 \%$ & $34.05 \%$ & $15.08 \%$ & $16.37 \%$ & $5.60 \%$ \\
\hline 7 & $\begin{array}{l}\text { Unnecessary use of antibiotics can increase the chance of } \\
\text { resistance of bacteria to them and decrease the future } \\
\text { effectiveness }\end{array}$ & $29.31 \%$ & $30.60 \%$ & $25.00 \%$ & $9.91 \%$ & $3.44 \%$ \\
\hline 8 & $\begin{array}{l}\text { Using full course of antibiotics can lessen the chance of } \\
\text { emergence of resistance }\end{array}$ & $15.94 \%$ & $32.32 \%$ & $36.63 \%$ & $8.62 \%$ & $4.31 \%$ \\
\hline 9 & $\begin{array}{l}\text { Poor drug quality and adulterated antibiotic preparation } \\
\text { can cause development of antibiotic resistance }\end{array}$ & $25.43 \%$ & $34.91 \%$ & $22.84 \%$ & $7.75 \%$ & $7.75 \%$ \\
\hline
\end{tabular}

$1=$ strongly agree; $2=$ agree $; 3=$ undecided; $4=$ disagree; $5=$ strongly disagree 
Table 3. Questionnaire to assess attitude

\begin{tabular}{|c|c|c|c|}
\hline SN & Quesitons & Yes & No \\
\hline 1 & $\begin{array}{l}\text { Do you usually take } \\
\text { antibiotics for cold or sore } \\
\text { throat? }\end{array}$ & $25.86 \%$ & $74.13 \%$ \\
\hline 2 & $\begin{array}{l}\text { Do you usually take } \\
\text { antibiotics for fever? }\end{array}$ & $37.5 \%$ & $62.5 \%$ \\
\hline 3 & $\begin{array}{l}\text { Do you stop taking } \\
\text { antibiotic when you start } \\
\text { feeling better during the } \\
\text { course? }\end{array}$ & $53.87 \%$ & $46.12 \%$ \\
\hline 4 & $\begin{array}{l}\text { Do you use left-over } \\
\text { antibiotics when you have } \\
\text { cold, sore throat or flu } \\
\text { without consulting your } \\
\text { doctor? }\end{array}$ & $18.10 \%$ & $81.89 \%$ \\
\hline 5 & $\begin{array}{l}\text { Do you buy antibiotics on } \\
\text { your own from a pharmacist } \\
\text { when needed? }\end{array}$ & $40.08 \%$ & $59.91 \%$ \\
\hline
\end{tabular}

students aged $18-20$ years related to antibiotic use. Based on the responses to knowledge based questions, we can relate that the students had a fairly good idea that antibiotics are medications used to cure infections but ironically the basic idea that, in general, antibiotics are only useful against bacterial infections was lacking as nearly $34 \%$ of students incorrectly agreed to the statement "antibiotics are useful against all types of infections" and almost $24 \%$ were undecided. This points a serious lack of knowledge among students and a possible misuse by them in infections which are not bacterial. This is further supplemented by the response of the students on the statement "antibiotics are needed to cure most coughs and cold" as $62 \%$ have agreed to this statement which is higher than the studies conducted in Britain ${ }^{17}$ and Lebanon. ${ }^{19}$ Such kind of lacunae in understanding the basic knowledge on use of antibiotics needs an immediate intervention by concerned authorities and a requirement of inclusion of 'rational use of antibiotics' in the school curriculum itself. Thus these findings indicate the necessity of launching specific interventions by identifying the priority areas of improvement specifically targeting the high school students and which can in general bring a favourable impact in a broader population. Similarly, while $60 \%$ students correctly responded that unnecessary use of antibiotics can lead to development of resistance by bacteria; nearly $37 \%$ of them were undecided and $12 \%$ disagreed to the statement whether completing full course of antibiotics lessens the chance of emergence of resistance possibly making them vulnerable to wrong practice of antibiotic use.

With regard to attitude associated with antibiotic use, majority of the students appeared to have right attitude based on their response to majority of the questions. But with regard to the question "Do you stop taking antibiotic when you start feeling better during the course?" majority of them $(53.87 \%)$ incorrectly answered "Yes". This correlates with the finding on knowledge section where $49 \%$ of students were incorrect with regard to the eighth question (Table 2). This is slightly higher than the frequency shown in previous study ${ }^{20}$ wherein $30 \%$ of the undergraduate medical students had responded that they stop taking further treatment after they start feeling better during the treatment with antibiotics. This can be attributed to the fact that the students in our study were non-medical and of high school level as compared to the medical students in the above mentioned study. But, this exposes the incorrect medication practice by students and thus increases the risk of emergence of antimicrobial resistance.

Also, $40 \%$ of the students responded that they buy the antibiotics on their own from a pharmacist when needed (Table 3 question 5). This frequency is slightly less as compared to the frequency in the study by Shah P et al ${ }^{16}$ wherein nearly $59 \%$ of the respondents had responded that they buy antibiotics on their own. Nevertheless, this exposes the height of prevalence of self-medication practice with antibiotics even in high school level students which is a matter of serious concern as antibiotic may not be necessary for the conditions and, even if it is necessary, questions of getting it correct for their condition still remains. Relevant laws, regulations, guidelines, etc. regarding the rational use of prescriptions and selling of antibiotics need to be formulated by the government, which can restrict the easy access to purchasing of antibiotics by patients and their relatives (including students) from hospitals and pharmacies. ${ }^{21,22}$ Majority of the respondents' (53.87\%) not completing the course of medication may also be explained on the basis of self-medication practice where proper diagnosis 
and emphasis on completion of the course of antibiotics is mostly lacking.

Our findings show necessity of highlighting knowledge on the rational use of antibiotics ${ }^{23}$ and also recommend using media approaches like TV programs or print media as well as conducting health education programs at school or at least high school level to disseminate knowledge on correct use of antibiotics. After all, the principal causes of emergence and the dissemination of resistant organisms is failure to implement policies and programs in preventing infections as well as failure to follow the antimicrobial usage guidelines strictly. ${ }^{24}$ The limitation of this study is that it was conducted in a single school with limited number of students and was not scaled up to assess the practice level.

\section{CONCLUSIONS}

The deficiencies in basic understanding about the nature and use of antibiotics and casual attitude in their use among high school students is a matter of great concern as it poses many serious problems including promotion of antibiotic resistance. Though larger scale studies are needed for more definite conclusions, our findings call for tailored interventions to be provided for high school students to clear their misunderstandings related to antibiotic use which will ultimately be useful to inculcate required attitude and improve the practice level on rational use of antibiotics.

\section{ACKNOWLEDGEMENT}

The authors would like to thank all the students who participated in the study as well as the school administration for their valuable time and support.

To cite this article: Sharma M, Kaundinnyayana S, Das P. Knowledge and Attitude Related to Antibiotic Use Among Students of a Kathmandu Based High School. MJSBH. 2021;20(2):142-7.

Conflict of Interest: None declared

\section{REFERENCES}

1. Shanthi M, Sekar U. Multi-drug resistant Pseudomonas aerugi-nosa and Acinetobacter baumannii infections among hospitalized patients: Risk factors and outcomes. J Assoc Physicians India. 2009;57(11):636-45. PMID:20214000

2. Woodford N, Livermore DM. Infections caused by Gram-positive bacteria: a review of the global challenge. J Infect 2009;59(1):4-16. DOI: 10.1016/S0163-4453(09)60003-7.

3. Containment of Antimicrobial Resistance. Available at: http://www.who.int/drugresistance/ WHO_Global_Strategy_English.pdf.

4. Chen C, Chen YM, Hwang KL. Behaviour, attitudes and knowledge about antibiotic usage among residents of Changhua, Taiwan. J Microbiol Immunol Infect. 2005;38:53-59. PMID:15692628

5. Nepal A, Hendrie D, Robinson S, Selvey LA. Knowledge, attitude and practices relating to antibiotic use among community members of the Rupandehi district in Nepal. BMC Public Health. 2019;19:1558. DOI: https://doi.org/ 10.1186/s12889-019-7924-5.

6. Okele IN, Laxminarayan R, Bhutta ZA, Duse AG, Jenkins P, O’Brien TF, et al. Antimicrobial resistance in developing countries. Part I: Recent trends and current status. Lancet Infect Dis. 2005;5:481-93. DOI: 10.1016/ S1473-3099(05)70189-4.

7. Awad AI, Aboud EA. Knowledge, Attitude and Practice towards Antibiotic use among the public in Kuwait. PLoS ONE. 2015;10(2):e0117910. DOI: https://doi.org/10.1371/journal.pone.0117910.

8. Thriemer K, Katuala Y, Batoko B, Alworonga J-P, Devlieger H, VanGeet C, et al. Antibiotic prescribing in DR Congo: a knowledge, attitude and practice survey among medical doctors and students. PLoS ONE. 2013;8(2):e55495. DOI: https://doi.org/10.1371/journal.pone.0055495. 
9. Pulcini C, Williams F, Molinari N, Davey P, Nathwani D. Junior doctors' knowledge and perceptions of antibiotic resistance and prescribing: a survey in France and Scotland. Clin Microbiol Infect. 2011;17(1):80-7. DOI: 10.1111/j. 1469-0691.2010.03179.x.

10. Vila J, Pal T. Update on antibacterial resistance in low-income countries: factors favouring the emergence of resistance. Open Infect Dis J. 2010;4(1):38-54. DOI: 10.2174/1874279301004010038

11. Charani E, Cooke J, Holmes A. Antibiotic stewardship programs-what's missing? J Antimicrob Chemother. 2010;65(11):2275-7. DOI: https://doi.org/10.1093/jac/dkq357.

12. Khan AK, Banu G, Reshma KK. Antibiotic resistance and usage a survey on the knowledge, attitude, perceptions, and practices among the medical students of a Southern Indian teaching hospital. J Clin Diagn Res. 2013;7(8): 1613-6. DOI: 10.7860/JCDR/2013/6290.3230.

13. Seid MA, Hussen MS. Knowledge and attitude towards antimicrobial resistance among final year undergraduate paramedical students at University of Gondar, Ethiopia. BMC Infect. 2018;18:312. DOI: 10.1186/ s12879-018-3199-1.

14. Kotwani A, Wattal C, Joshi PC, Holloway K. Knowledge and perceptions on antibiotic use and resistance among high school students and teachers in New Delhi, India: A qualitative study. Indian J Pharmacol. 2016;48(4):365-71. DOI: $10.4103 / 0253-7613.186208$.

15. Nayak S, Rana M, Mayya S, Gupta GP, Wazir SS, Parmar KS et al. Antibiotics to cure or harm: Concept of antibiotic resistance among health professional students in Nepal. Int J Med Sci Public Health. 2016;5(12):2512-7. DOI:10.5455/ijmsph.2016.14052016515

16. Shah P, Shrestha R, Mao Z, Chen Y, Chen Y, Koju P et al. Knowledge, Attitude and Practice associated with antibiotic use among university students: A survey in Nepal. Int J Environ Res Public Health. 2019;16:3996. DOI: https://doi.org/10.3390/ijerph16203996.

17. McNulty CA, Boyle P, Nichols T, Clappison P, Davey P. Don't wear me out - the public's knowledge of and attitudes to antibiotic use. J Antimicrob Chemother. 2007;59:727-38. DOI: 10.1093/jac/dk1558.

18. McNulty CA, Boyle P, Nichols T, Clappison P, Davey P. The public's attitudes to and compliance with antibiotics. J Antimicrob Chemother 2007;60:63-8. DOI: 10.1093/jac/dkm161

19. Jamhour A, El-Kheir A, Salameh P, Hanna PA, Mansour H. Antibiotic knowledge and self-medication practices in a developing country: a cross-sectional study. Am J Infect Control. 2017;45(4):384-8. DOI: 10.1016/j.ajic. 2016.11.026.

20. Padmanabha TS, Nandidni T, Manu G, Madhav K, Savkar, Ravi Shankar M. Knowledge, attitude and practices of antibiotic usage among the medical undergraduates of a tertiary care teaching hospital: an observational crosssectional study. Int J Basic Clin Pharmacol. 2016;5(6):2432-7. DOI:10.18203/2319-2003.ijbcp20164100

21. Zafar SN, Syed R, Waqar S. Self-medication amongst university students of Karachi: Prevalence, knowledge and attitudes. JPMA. 2008;58:214-7. PMID: 18655436.

22. Metlay JP, Shea JA, Crossette LB. Tensions in antibiotic prescribing: Pitting social concerns against the interests of individual patients. J Gen Intern Med. 2002;17:87-94. DOI: 10.1046/j.1525-1497.2002.10711.x.

23. Rusic D, Bozic J, Vilovic M, Bukic J, Zivkovic PM, Leskur D, et al. Attitudes and Knowledge Regarding Antimicrobial Use and Resistance among Pharmacy and Medical Students at the University of Split, Croatia. Microb Drug Resist. 2018;24(10):1521-8. DOI: 10.1089/mdr.2018.0010.

24. Nathwani D, Davey P. Antibiotic prescribing-are there lessons for physicians? J Med. 1999;92(5):287-92. DOI: https://doi.org/10.1093/qjmed/92.5.287. 